\title{
'You are Too Square, I Need to Straighten You Out' The Tamed Rebels of 1950s Coming-of-Age Films in Cross-Cultural Perspective
}

\author{
FRIEDEMANN J. WEIDAUER \\ UNIVERSITY OF CONNECTICUT
}

'You are too square, I need to straighten you out!' Perhaps unconsciously, this quote from The Wild One ${ }^{1}$ with its catachrestic metaphor spells out the contradictory message of many coming-of-age films from the 1950s. Critics don't seem to be able to establish whether the teen-pics of this decade exploited public fear of a juvenile delinquency epidemic, helped fuel this fear ${ }^{2}$ or, as 'paeans to conformity', did the opposite. ${ }^{3}$ As I will show, they actually did all three things at the same time. In the context of the social conditions of the 1950s the films picked up on a phenomenon visible to all, and in doing so they struggled with contradictions and conflicts for which there is no resolution. No one is able to establish to what extent movies have a direct influence on their audiences except in those rare instances when the showing of a movie evokes a direct reaction from the audience at hand. But it is obvious that the moves and looks of James Dean and Marlon Brando influenced teenage

\section{ISSN 1837-8692}

Cultural Studies Review 2015. @ 2015 Friedemann J. Weidauer. This is an Open Access article distributed under the terms of the Creative Commons Attribution 4.0 Unported (CC BY 4.0) License (https://creativecommons.org/licenses/by/4.0/), allowing third parties to copy and redistribute the material in any medium or format and to remix, transform, and build upon the material for any purpose, even commercially, provided the original work is properly cited and states its license. 
moviegoers of the 1950s to a considerable degree. Similarly, the films picked up on what could be called a public obsession with juvenile delinquency at this time and on the waves of 'moral panic' ${ }^{4}$ that accompanied it, which guaranteed them a certain amount of box office success. But looked at in this way, any film that picks up on contemporary concerns could be perceived as exploitative. Whether they seek to harmonize or to exaggerate the problem at hand, at least partially they do so for marketing purposes, addressing, in the case of the former, the parents as potential customers, and in the case of the latter, the youths themselves. ${ }^{5}$ Further, as the contradictions in society that the teen movies address have no real resolution within the context of the respective economic systems, the films need to end with 'false closure(s)' (as has been remarked about Rebel without a Cause). ${ }^{6}$ Within this logic, they have to come down on the side of conformity and cast the rebellious aspects of the protagonists aside or channel them into acceptable forms of behaviour. They offer a temporary solution to a problem that will continue to exist, and thus, they create the need for more films of their kind as the cathartic effect on the audiences wears off and the underlying problems persist. ${ }^{7}$

The films discussed here are The Wild One (1953), Rebel without a Cause(1955), Die Halbstarken (usually translated as Teenage Wolfpack, West Germany, 1956), and Berlin-Ecke Schönhauser (Berlin-Schonhauser Corner, East Germany, 1957). ${ }^{8}$ Although these films represent only a fraction of the films of that time period depicting rebellious youths, they came out in rapid fire sequence on both sides of the Atlantic which, if we hadn't known this already from other sources, would suggest something was afoot in industrialised countries during the 1950s. This article shows that the generation depicted in these movies (and the generation of younger viewers addressed by them) experienced a period of exhilarating freedom early on in their lives. This freedom was as scary as the freedom depicted in existentialist philosophy that was in vogue at this time, a freedom in fact so scary it almost always leads to flight into conformism. Thus, the films reflect and build on the dichotomy between boundless freedom and a strong desire for safety and boundaries. Simultaneously, they evoke the boundless entrepreneurial spirit on which capitalism thrives and channel it into socially acceptable forms.

There is a direct link between the East and West German films and the earlier US films, through a number of quotes and allusions. It is of course difficult to 
establish if the genre itself simply suggests a certain cinematic iconography (clothing, hairstyles, outbursts of violence, motorcycles and other means of transportation denoting 'freedom', 'off the grid' spaces like the abandoned house in Rebel without a Cause, and so on), but if elements of the iconography are not motivated from within a film's narrative, it is fairly safe to assume that they serve as quotes from other films. This is the case with the gang of motorcyclists appearing at the conclusion of Teenage Wolfpack. We are in an affluent part of West Berlin around dawn on a Sunday morning: at this point in the film, a herd of camels would have as much or little motivation for its appearance as this gang. In addition, the motorcyclists wear helmets as if to suggest the stifling atmosphere of postwar West Berlin-in contrast to the sense of freedom surrounding the gang in The Wild One.

Similarly unmotivated, in a scene in which one would expect some idle love chatter between Dieter and Angela during one of the few moments in which they are alone in Berlin-Schonhauser Corner, Dieter brings up his dream of buying a motorcycle. This is twice removed from The Wild One, as the audience would consider how long it would take Dieter to save for it and how long he would then have to wait for this, as for other consumer products in East Germany. Dieter also asks Angela if she would fall for someone with the looks of Marlon Brando. She leaves this question open, but again it is an instance of The Wild One appearing in the film, though twice removed from the reality of East Germany. Ekkehard Schall (Dieter) something of a celebrity in East Germany as a relative of Bertolt Brecht, was an actor in the tradition of his famous relative's 'epic theatre' that emphasised the distance between the actor and his or her role, the antithesis to Hollywood realism.

These and other quotes from US models in the German movies invite their audiences to make comparisons between their own situation in a divided Germany and that of their peers experiencing the postwar economic boom in the United States. They also introduce into these movies the United States in its role as father figure in a twofold sense: as the home of a movie industry that is on the one hand admired for its technical brilliance and on the other loathed for the way in which it economically stifled the indigenous film industries of West Germany and pre-Wall East Germany and sometimes made them seem like clumsy imposters. Economically, too, the United States was both envied as a land of plenty and perceived as the source of a kind of wasteful behaviour destined to undermine old-fashioned German 
Haushalten (economical house-keeping). This lends the German films a certain additional urgency as they explore how the next generation will deal with these temptations. Will they simply mimic the behavior of their US counterparts or will they keep a national identity in the face of the onset of economic well-being and a consumer culture influenced by the United States?

But what distinguishes the rebels of this wave of films from those from other periods in film history when the teen genre was popular? They tend to be around eighteen years of age in the mid 1950s, thus they were born (if we think of them as real life characters) in the mid to late 1930s. Their peer in the realm of literature is the protagonist Nick in Don DeLillo's novel Underworld. ${ }^{9}$ Nick shot a man as a juvenile, spent time in a correctional facility, but grew up to be a successful manager in a waste-handling company. In reflecting on his life from the vantage point of an adult in his mid fifties, he concludes: 'Most of our longings go unfulfilled', ${ }^{10}$ adding:

I drink aged grappa and listen to jazz ... and I know the ghosts are walking the halls. But not these halls and not this house ... I long for the days of disorder. I want them back, the days when I was alive on the earth, rippling in the quick of my skin, heedless and real. I was dumb-muscled and angry and real. This is what I look for, the breach of peace, the days of disarray when I walked real streets and did things slap-bang and felt angry and ready all the time, a danger to others and a distant mystery to myself. ${ }^{11}$

If we had a soliloquy of the Marlon Brandon character Johnny in the film The Wild One it would run approximately along these lines. The section in which Nick contemplates his earlier self from the distance of about thirty-five years is, of course not by coincidence, entitled 'Das Kapital', in the original German of Karl Marx' multivolume analysis of the capitalist system. The title links the contradiction of Nick's two selves to the contradictions within this particular economic system. And Nick is, of course also not by coincidence, a manager working for a waste disposal company, the company that deals with the excesses this system casts aside but also preserves and recycles. The ghosts that are walking the halls have their material equivalent in the trash of the 1950s that waits in the covered up garbage dumps below the surface of new suburbs. At the same time, Nick's brother Matt is still dealing with the main fear the kids of this generation had to confront, the possibility 
of annihilation through a nuclear bomb. As a physicist for the arms industry he is helping to design those same weapons that created the scare.

But these longings for the 'days of disarray' only surface momentarily and do not lead to any attempts by the individual to recapture the reality of that other life. As early as 1961 when this generation had arrived in their late twenties, a Gallup poll could conclude:

No one can say that the American youth is going to hell. He's not. But he is a pampered hothouse plant and likes it that way. The beatnik is a rarity, the delinquent a minority. Our typical youth will settle for low success rather than risk high failure ... He wants to marry early ... wants two or three kids ... a little ranch house ... a job with a large company ... He is old before his time; almost middle aged in his teens. ${ }^{12}$

A search of real life specimens of this generation brings up the names of Philip Glass, Colin Powell, Bill Cosby, Dustin Hoffman (all born in 1937), Patrick Buchanan and Bernard Madoff (1938) as well as Dennis Hopper and Kris Kristofferson (1936). With the exception of Madoff and Hopper these people have not been life-long rebels. In the case of Madoff we could say that he tried to solve Nick's dilemma by inserting the days of 'slap-bang' into the system, rather than seeing it as something it cannot contain. But only a few years later we find the representatives of a generation that kept their spirit of rebellion alive for decades: C. Clark Kissinger of the SDS (1940), Stokely Carmichael of the Black Panthers (1941), Peter Coyote of the San Francisco Mime Troupe along with Joan Baez and Bob Dylan (also 1941), as well as Rudi Dutschke, the leader of the West German student movement, but also Frank Zappa and John Lennon (born in 1940). A quote from Blackboard Jungle shows us the difference a few years can make. The protagonists of the 1950s teen movies 'were five or six years old in the last war. Father in the army, mother in the defense plant, no home life, no church life, no place to go. They formed street gangs...'. The split in their lives runs along the divide between a time perceived as one of unbelievable freedom when they were, so to speak, parentless, and the perception of the same time as one of great anxiety and uncertainty with several uncontrollable threats crowding in on them. In the German context one speaks of the rubble kids, the ones that played among the ruins, often with leftover live ammunition, forming their own societies in gangs. An earlier film, Irgendwo in Berlin 
$(1946),{ }^{13}$ can give audiences today a sense of these years. Life in the ruins of the bombed out cities was exciting and full of adventure, but also scary and truly dangerous. As it looks, this generation immediately seized the first opportunity of a safe and stable life, whether it was the postwar boom in the United States or the Wirtschaftswunder in West Germany, the first chance of starting that family with two to three kids in the little ranch house (or the German equivalent, the Reihenhaus) they could now afford. In Irgendwo in Berlin from East Germany, where private property began to be looked down on in the wake of the installation of a Sovietbacked socialist system, the kids are happy when their energies are directed into rebuilding a bombed-out car repair shop.

Quite in contrast to this, the generation born after 1940 appears to have had a childhood stable and safe enough to form the foundation for a lifetime of rebellion. They had not experienced the down side of almost absolute freedom, but only increasing wealth and conformism that seemed to smother all spontaneity. The filmmaker Wim Wenders (born 1945) and the poet Rolf Brinkmann (1940), to give examples from West German cinema and poetry, perceived the 1950s as a time of unbearable boredom and philistinism. Wenders once claimed, 'My life was saved by Rock'n Roll', ${ }^{14}$ music he couldn't hear on West German radio but only by way of the American Forces Network.

There are a few other factors that set these generations apart. The birthrate in the United States was at a historical low from 1935 to 1940 due to the Great Depression and World War II; it would not hit another all-time low until 1970. ${ }^{15}$ Consequently, it probably didn't strike contemporary audiences as peculiar to find more and more single children on the screen-for example Jim and Plato in Rebel without a Cause, or Sissy in Die Halbstarken and Angela and Karl-Heinz in BerlinEcke Schönhauser. We could speculate that this demographic factor contributed to the feeling of insecurity of this generation as siblings, to some degree, could not make up for the parents who had gone missing. At the same time, the median household income rose 30 per cent from the 1950s to the 1960s, an unprecedented increase that has not been seen since as incomes started to level off in the 1970s and have stayed flat or gone down since. ${ }^{16}$ Again, the generation born in the second half of the 1930s, the generation depicted in 1950s teen movies, was confronted with a contradiction when growing up that must have been hard to make sense of: they 
experienced years of need followed by a sudden onset of wealth. The generation of a few years later was born into this wealth and could look upon their parents' pursuit of more material wealth with scorn, while those who had experienced need, and even hunger and death, could not afford the luxury of such an attitude.

The divide between these generations runs roughly parallel to that identified in the German context as the difference between the '45ers' and the '68ers'. ${ }^{17}$ The '45ers' were too young to experience wartime and the ruptures that came with it with the consciousness of an adult, yet they did go through them in one way or another. Because of this, their experiences formed a collective unprocessed trauma. This applies to their US counterparts as well: 'normal' family life was unexpectedly interrupted only to be continued a few years later under changed economic conditions. What the next generation, the '68ers', learned about this was mediated through historiography and the unreliable accounts of their parents' generation and so they gained some intellectual distance from the turmoil their parents had undergone. The '45ers' would rather repress than process the traumatic experiences of these times and therefore yearned for the kind of safety found in the description of the Gallup poll quoted above. After 1945 the reestablishment of an order that seemed to safeguard the private sphere, which had been violated in the years before, made conformity to this order a more attractive path than rebellion. The desire for a safe home and a family that all protagonists of 1950s teen films express is the logical outcome of this situation. This generation felt the need to come to some kind of accommodation with the generation of their fathers rather than confront them in a rebellious stance for a long period of time. They saw their parents as victims of the same circumstances that had traumatised them, as worthy of pity rather than disdain. ${ }^{18}$ The cinematic logic of this accommodation between generations can be seen in the clumsily staged reconciliations between fathers and sons in Teenage Wolfpack and Rebel without a Cause. When early in Rebel without a Cause James confronts his father, who is dressed in an apron and cleaning the house, about what it means to be a man, it sounds like the desperate expression of a question both generations were at a loss to answer, not one that divided them or to which they had found different answers. The trust Dieter displays in the East German policeman in Berlin, and the arrangement between Johnny with the local police in The Wild One that allows him to see Kathie again, are variations on this theme. In addition, the 
accommodation of the German '45ers' with the status quo was overdetermined by their admiration of the United States as a kind of father figure that guaranteed the stability of the new postwar system, a form of 'redemptive republicanism'. ${ }^{19}$ All of this made them seem even more suspicious in the eyes of the next generation, the '68ers'.

What appears to emerge as a pattern is that social and economic factors for the generation of the Johnnies and Jims colluded to make the already difficult phase of coming of age even harder. In a very general sense, one could say that adolescence is that phase during which young people realise the potential freedom of a life beyond the safe and narrowly circumscribed environment of their childhood. It comes at a point when they are not yet ready to perform or accept the responsibilities that come with this freedom. It is also when young people start to sense that the cards are stacked against them, as others, such as the older generations, stand in their way. Because of this, they tend to display a certain amount of self-pity, which is always at least partially justified. ${ }^{20}$ As almost all teen movies focus on this aspect in the development of the individual, I would argue that the understanding of the coming-of-age genre as depicting the transition from childhood to adulthood should be expanded to include almost all teen movies, except perhaps those that simply use teens as props for other purposes, as the seemingly endless list of subgenres in Doherty's Teenagers and Teenpics illustrates. ${ }^{21}$ The first sense of freedom for this particular generation of teenagers came with a strong sense of dread and uncertainty as the chaos of the war years they had experienced as children resurfaced in the form of a possible nuclear war in their adolescence. The promise of freedom was immediately tainted by the memory of possible or real chaos. It is no wonder then that the protagonists yearn for nothing more than a stable, safe family life. Jim and Judy fantasise about this in the abandoned house in Rebel without a Cause where they play 'house', and even Johnny, the wild one, smiles in the direction of Kathie in a way that seems to indicate he is ready to come in from the wild. That smile, in the final scene, makes up for all the lines he hasn't said up to this point.

Some of the most fundamental contradictions that shape life in a capitalist society, whether the tension between community and individual formulated by Sobchak or the desire to return and stay home versus the drive to keep wandering as formulated by Wood, are most visible to young adults: ${ }^{22}$ in the instant they sense 
a new freedom they are confronted with the limits imposed on it by the demands of society. I would like to go further and claim that in this phase of life, young adults are being confronted with the inherent contradictions of capitalist ideology for the first time, in a way that catapults them out of a life of relative harmony into a mess of irreconcilable demands. Before, they had been told to share and to cooperate; now they realise that individual freedom guaranteed by a certain degree of wealth has to be gained at the expense of others. They had been told that everyone can succeed if they put in some effort, but they now realise that wealth and success is limited and distributed unevenly, not necessarily on the basis of merit; now just as the materialism surrounding them begs them to consume, they have to learn to limit their appetites to the things they can afford; in pre-school and kindergarten they were taught to use their 'indoor' voice, but they now find out that the loudmouths rule the world. Above all, they learn that to participate in the freedoms of a consumer society they have to subject most of their waking hours to the wills of others to earn the money they need to participate in that society. It is again no coincidence that the factor that imposes a degree of discipline on the life of the Nick character in DeLillo's novel is his desire to consume and hence the necessity to commit to the life of a working person. You are an adult, it has been said, if you go to bed at a reasonable hour voluntarily, because the working life requires it. Along the way, young adults also learn that while they have been told they live in a democracy, they will spend the vast majority of their lifetime in institutions that are not democratic, whether it is the family, a job, church, school or university. The life of the adult, in the terminology of Karl Marx, becomes split into the life of the citoyen, the good neighbour and family man, and the bourgeois that seeks to annihilate his competitor. $^{23}$

As a result, it is a common aspect of coming-of-age films and books that adolescents perceive the adults as phony because they are still aware of these contradictions while the adults have learned to live with them more or less successfully. It has been said about Holden Caulfield in The Catcher in the Rye: 'That he sees things accurately is precisely the problem. ${ }^{24}$ This also applies to the protagonists of the coming-of-age films, as does the question: 'What truths about life is the adolescent better stationed to see than either the child or the man?'25 The adolescent sees the many contradictions of life under capitalism and consumer 
democracy—contradictions to which these films, like their protagonists, can find no answers.

Because of this, all coming-of-age movies have to offer 'false closures' as there cannot be true ones. ${ }^{26}$ If the films did offer radical new possibilities and solutions, they would have to go beyond the confines of the social system in which they are being produced. Any films that did this would most likely not even make it into the production stage, given the form of censorship this system practices. On the other hand, in an extension of the arguments of Wood and Sobchak, one could say that this is what drives the movie industry. It has to keep taking up these problems without ever being able to come to permanent closure: the resolution at the end of each movie already again contains the contradiction the film intended to work out. As Wim Wenders tried to show in his film Im Lauf der Zeit (Kings of the Road, 1976) the film industry has to keep promising the emotional fulfilment of neat closures while eventually always delaying or denying any such thing. ${ }^{27}$

But how are these problems worked through in the movies? First, as an external sign of this transitional phase in life, to show that the protagonists are between two phases in their lives, they are often obsessed with certain transitional objects. In The Wild One this is carried almost to the point of parody in Johnny's obsession with the race trophy he steals at the beginning of the movie. He ties it to the handlebar of his motorcycle, he fights over it and it is also the most precious thing he can offer to Kathie. In Rebel without a Cause we first see Jim holding and petting the toy monkey, later he clings to Judy's notebook. Freddy, in the West German film Die Halbstarken, adopts a dachshund that he and his buddies found in a stolen car. His affection for the dog at a point in the movie when things have started to go wrong plays a role in undermining his authority among his friends. While the transitional object allows others to see the vestiges of the childhood phase the protagonists are trying to cast aside, giving up the transitional object, which usually happens at the end of the films, can then be seen as the successful entry into adult life. In a variation of this, we also often see the protagonists give up the external markers of their rebellion, as Jim drapes his red jacket over Plato, or when, towards the end of The Wild One, Johnny parks his motorcycle according to the city ordinances and, for the first time, has a conversation with Kathie without this prop to back him up. The structure of these scenes resemble the moments when the 
heroes of screen westerns have to decide whether to settle down or to move on (see, for example, Ethan in The Searchers), ${ }^{28}$ but while in westerns the heroes usually decide to move on, in coming-of-age movies they almost always settle down. It is their darker shadows that move on, either into the Great Beyond (Plato and Buzz in Rebel, Kohle and Karl-Heinz in Berlin) or just further down the road (Chino in The Wild One).

This is in fact one of the techniques used to gloss over the contradictions experienced by the adolescent protagonists that cannot really ever be resolved: the two sides of the divide are represented by two separate characters. While one character will not put up with restrictions on his freedom, and hence must perish, his counterpart will settle into some kind of peaceful coexistence with the rest of society. Johnny's counterpart is Chino, and he really is the wild one. Chino is clearly beyond redemption; he has chosen the uncompromising pursuit of excess and cannot ever become a responsible consumer because enough is never enough for him, whether it is beer, violence or sex. His excess of desire is most prominent when he crosses gender lines; he says, 'I love you Johnny' whenever he sees him and, with other members of his gang, cross-dresses on various occasions. It is made clear that Plato represents Jim's unredeemable cousin in Rebel without a Cause the moment we hear he had drowned some puppies; Plato's excess of anger against the world around him is thus labelled pathological and would have attracted psychiatric care if he hadn't conveniently died at the end of the movie. In Die Halbstarken, Freddy's dark side is represented by his girlfriend Sissy in a twist on the same mechanism. It is Sissy who insists on going back for another heist when Freddy's plan has failed miserably and he is ready, it seems, to reenter bourgeois life. Sissy's own excess is overdetermined by the fact that she explicitly rejects the role of the good wife. She hates cooking and refuses to help her mother with chores-thus she clearly would not be able to provide Freddy with the safe home he yearns for.

We find another false closure in the conflict between possible gender roles when Judy in Rebel without a Cause switches sides and quits Buzz' gang to become Jim's girlfriend. The biker chicks in The Wild One are beyond salvation and annoy Johnny with their aggressive sexual advances, but in Rebel without a Cause, in the span of a few minutes after Buzz's death, Judy converts to being the potential future wife of Jim. She had waved the flag to start the 'chickie run', then moments later, 
with Buzz still lying dead at the bottom of the cliff, she undergoes a rapid transformation into Jim's soul mate. This will be confirmed in the sequence in the deserted house when Judy and Jim dream of their future roles as parents who will not do it differently from their parents, just better. The message appears to be that some are just waiting to be relieved of their role as a rebel, while others are hardwired for a lifetime of trouble-making. The way the movies here deal with the real problems behind teenage rebellion resembles the rigid moralising of old style fire and brimstone sermons according to which some can be saved and others will be damned.

A similar tactic to arrive at false closures is to shift resolution from the real conflict in the coming-of-age films to a problem that can be solved more easily. ${ }^{29}$ The chaos produced by Plato and the subsequent reintroduction of order by the police in Rebel without a Cause distracts from the fact that Jim's father's assurances he will be a better role model in the future require a fairly big leap of faith. Jim's original question, 'What does it take to be a man?', remains unanswered. Similarly, in The Wild One, the fact that Chino's gang is out of the picture (but where did they go?) makes it more believable that Johnny and Kathie will cast their wild sides aside and enter into middle-class family life. In the German Die Halbstarken the thoroughly evil Sissy is arrested, and we can now have hope for Freddy, though his original problems have not been addressed. As if to show that Freddy's wild side has been externalised, we see the pack of men on motorcycles come by as he hangs wounded in his father's arms. They look like domesticated ghost riders from Chino's gang.

The East German movie Berlin-Schonhauser Corner (1957) offers yet another, socialist, twist to the coming-of-age genre. Kohle, the dark shadow of the protagonist Dieter (perhaps the nickname is supposed to allude to this dark side, kohle is the German word for coal), is doomed by his obsession with movies from the West on which he spends every single penny of his meagre allowance. The lure of the West is so strong that it seems impossible he will ever be converted into a good socialist citizen, and thus he has to die. Dieter is linked explicitly to the character played by Marlon Brando in The Wild One and will find his place in the midst of society. Ironically, by naming Brando, Dieter seems to sense the same attraction to the Brando character that Chino displays in The Wild One ('I love you, Johnny!'). Angela, his girlfriend, on the other hand falls in the category of Judy and Kathie-like women. 
Judy showed her wild side during her membership of Buzz's gang while Kathie showed her during her motorcycle ride with Johnny. During this sequence she hugs and fondles his motorcycle, in place of him. Angela has enough wildness to attract Dieter initially (she has to spend many hours out on the street of Berlin while her mother spends time with her lover in their cramped apartment), but also emits enough signals to make her eligible as a future wife. As mentioned earlier, one of the most intimate confessions Dieter makes in Angela's presence is that he wants to buy a motorcycle. While this reaffirms his link to Johnny, in the context of East Germany it also means that he will give up many freedoms to save for this object of desire. As it turns out, the fetish of freedom, the motorcycle, is what will make a disciplined worker out of him, as he becomes willing to transform leisure time into overtime in line with economic measures taken at this time that introduced Western-style incentives into the workplace under the name 'socialist competition' (sozialistischer Wettbewerb).

The other symbols of rebellion are also costly, whether they be cars, motorcycles or fashionable jackets. These objects embody the dual character of temptation in a consumer society: they promise freedom, but come at a price. The price can be paid either by choosing the path of constant rebellion, by becoming the outlaw that takes what he wants, or by subjecting oneself to the discipline of a regulated work day. Thus, youths can be either potential customers or looters. Johnny shows the transition from looter to responsible customer when he orders a cup of coffee in the town where, earlier, members of his gang had emptied the local bar's supply of beer-most likely without paying for it, though initially the bar's owner saw them as a welcome economic stimulus. The camera lovingly focuses on the teaspoon that is put next to Johnny's cup of coffee as if to emphasise the 'healthy' economy of this purchase.

In the German movies excess consumption is linked to icons of American culture. Freddy really wants an American car, a Buick, and not an Opel, General Motors' German subsidiary. In the case of the budding economic miracle, it seems, consumer dreams have to be scaled down further; a Buick, though within reach for the US adolescents in Rebel without a Cause, would necessitate a life of crime in the case of West German youths. It is the wish to buy the Buick on display at the gas station where Freddy works as much as Sissy's desire to live a life of luxury that 
makes Freddy dream up the plan to rob a mail transport-a plan so far-fetched it seems Freddy unconsciously wants to be caught in the process of putting it to work. It is noteworthy that in this film the threat to West German society does not come from right across the border, from socialist East Germany, but from the promise of too much from across the Atlantic. ${ }^{30}$ It is also interesting to note that the films, by way of channelling excess desire into responsible consumerism, also channel the fluctuating gender constructions of the immediate postwar period back into their traditional paths. ${ }^{31}$ In fact, these go hand in hand: the female protagonists, once their wild side has attracted their male counterparts, become domesticated and scale their wishes to what can be attained by their future husbands' honest work.

Parallel to the reestablishment of gender roles that had been upset by the special circumstances of the war years, we see a 'reempowering of the fathers' generation', 32 the accommodation described earlier between the fathers' generation and the '45ers'. As one scholar remarked, 'teen film presides over the eventual discovery of viable and often traditional forms of authority'. ${ }^{33}$ Sometimes this happens by proxy through police forces that reestablish order, but the actual fathers are usually nearby. In both Rebel without a Cause and Halbstarken, in the final minutes of the film the protagonists' fathers ride to the scene with the police, and in both films the crises at the end lead to a cathartic realisation for the respective fathers that they will now have to behave as reconfigured father figures. They gain some of their new-found authority through their association with the police officers who are more in tune with the younger generation, without which the turnaround would be somewhat hard to believe.

In the other two movies, Berlin and Wild One, the fathers' generation is only represented through police officers who in both films 'take a big fat chance' by letting the juvenile delinquents go, trusting they have learned their lesson, adapted to the adult world and will come out of the crisis okay. In The Wild One, we see the police forces make an exception for Johnny as they let him into the café for the chance to give his promising smile to Kathie, even though he and his buddies had been banned from the town. In Berlin's final voice-over the police officer even takes part of the blame for the crisis upon himself. He promises to be even more vigilant in the future, stating that 'where we cannot be, we will find our enemy'. This police officer even represents an improvement over the police officer Ray Fremick in Rebel 
without a Cause as he can actually always be found where he promised the protagonist he would be. On the other hand, the absence of the police officer at a decisive moment in Rebel without a Cause gives Jim an opportunity to show his maturity (that is, his conformism), as although disappointed he does not go berserk-unlike Plato when he can't find Jim in the abandoned house. Plato's disappointment here triggers the psychopathic behaviour that initiates the resolution of Jim's part of the story. The authority of the police is softened by their ability to understand the younger generation and their willingness to give the young ones another 'big fat chance' in a strategy later termed 'repressive tolerance' by Herbert Marcuse, who saw it as a form of tolerance meant to maintain political stability rather than entertain divergent views. ${ }^{34}$ This was something that would drive the next generation of rebels insane, but seems to have worked quite well for this earlier generation. In both films, police understand the youths even when the youths refuse to speak to them. Sometimes, though, police officers are able to make the rebels express their rage in words. Ray in Rebel without a Cause triggers an outburst of words from Jim that resembles a breakthrough session in psychotherapy. This version of mellowed authority also makes the initial nondiegetic warnings about the events depicted in The Wild One and Halbstarken seem very out of place. The films advocate a reformed, more liberal form of authority, while the non-diegetic warnings come in the form of the raised index finger ala Struwwelpeter and other tricks from the box of repressive pedagogy. On the other hand, these warnings do remind us that in the political arena of these years, at least, this kind of repressive behaviour was still rampant, whether the activities of Senator McCarthy in the United States or those of Chancellor Konrad Adenauer in West Germany, who ran a reelection campaign on the platform 'no experiments' (that is, no big fat second chances).

The reintroduction of state authority by way of reformed father figures is again closely linked to the economic system as they owe a large amount of their authority to the fact that they were the ones that made the economy hum again. In addition, as seasoned crisis managers they seem to have a better grip on the future than the next generation that is always at risk of descending back into their trouble-making mode.

Just as the excessive material desires of youths had to be channelled into forms of responsible consumerist behaviour, their wish for a social life not dominated by 
'phoneys', for a community of soul mates, needed to be channelled into the only acceptable form it could take in a capitalist society, the nuclear family. The only way Plato could imagine social contact of a positive kind is to make Judy and Jim into parent figures. This is also the reason he runs amok when he can't find them in the abandoned house. As soon as the rebels and their present or soon-to-be girlfriends get a little closer, talk about family and kids comes up. On the other hand we have the unacceptable 'commune' of Chino's gang called the Beatles. While they seem to have an excessively good time most of the time, their way of associating with each other is linked to forms of behaviour that contemporary audiences would have wanted to avoid at all cost, such as cross-dressing, boys dancing with boys and, of course, the open declarations of love by Chino for Johnny. The only way to channel this kind of homoerotic energy is to stage not one but two fist fights between Chino, who has crossed the gender lines, and Johnny, who seems a little repressed, but at least will never stray from the straight and narrow. Similarly the aggressive sexuality of the biker chicks finds an acceptable counterpart in Kathie's loyalty to her own family and, by implication, her loyalty to this form of human interaction. And again, in Halbstarken the 'bad' girlfriend, the unfit future wife Sissy, is removed by the police.

The one exception to this support of the nuclear family is Berlin, and here we can see the coming-of-age film reconfigured in the context of a socialist society. The bourgeois family is portrayed as the source of most evils in society: the person who willingly commits crimes is from the only family in the film where both biological parents are alive, the person who ends up accidentally dead is from a family headed by his biological mother and stepfather, and the promising future husband of the future family emerging from the gang of troubled kids is an orphan and his future wife half orphaned. The further each kid is removed from the background of an intact biological family, the film seems to suggest, the better the chances are they will lead a good life in the emerging socialist society. Society as a whole is a better family than the bourgeois nuclear family. In fact, at a point when Angela is being forced to bring up her child without a father during the time Dieter spends in the West, the larger community pitches in. The policeman happens to come by when Angela is wandering the streets of Berlin alone, perhaps contemplating suicide, Dieter's brother makes room for the mother-to-be in his tiny apartment and his 
landlady pitches in some fruit so she can eat healthily. The non-diegetic voiceover at the end seems to assure us that this child will have a future even without an intact family, though Dieter's glance up towards Angela's window is as promising as Johnny's smile for Kathie. This in a sense reflects the contradictory social policies of East Germany which of course would have to assure everyone that society can move beyond bourgeois social institutions, but at the same time, there's still the bourgeois nuclear family-just in case. On the other hand, this film is the only one that dares thematise the ever-present possibility of an unplanned teenage pregnancy, and it finds a happy ending to a situation that in films from the West usually lead to morally awkward compromises.

Another aspect the film from socialist East Germany handles differently is its portrayal of the next generation as the one with whom the hope of society rests. US and West German films, even at the end, still see the younger generation as potential troublemakers who will need a firm hand for some time to come. The policeman in Berlin is markedly older than the policemen in the Western films and he seems ready to hand the reins over to the next generation; the policemen in the other films are somewhere in their middle age and have decades of influence on the younger ones in front of them before they go into retirement. In addition, the protagonist in Berlin seems more mature and the learning process he undergoes is somewhat more believable, not a precarious development brought on by a course of events that others have triggered (Plato's shooting, Chino's anarchism, Sissy's criminal strain). In an early scene in the movie, he manages to move a dud left over by the war away from other workers so it doesn't do any harm when it explodes. He also refuses to participate in a scheme to sell East German IDs (a hot item during pre-Wall times, as they allowed their holders to buy subsidised food items in the East), and when he gets into trouble it is only out of solidarity with Kohle, the Plato-like character. He follows Kohle to the West and then upon Kohle's death immediately and voluntarily returns to the East to report to the policeman what happened. In contrast to Ray in Rebel without a Cause, the policeman is where he is expected to be. In real life politics of East Germany in the 1950s, too, old men (Walter Ulbricht for example) stayed in power for decades to come, but this state had also not yet given up on shaping a society that would consist of a new breed of individuals. In the Western films the vague longing of adolescents for community found in their membership of 
a gang or group of peers needs to be channelled in the direction of the traditional family; in the East German film it is the socialist society as a whole that provides a home for the rebel upon his return.

What all these films have in common is that contrary to the title of its most famous example, there is always a cause for rebellion. As Chino puts it in a sentence that implies a certain awareness of the political dimension of what he and his gang is doing: 'Storm the Bastille!' His remark is a reminder of the French Revolution's promise of liberté-egalité-fraternité, a promise that of course remains forever delayed but that his gang, at least momentarily, makes come true. Though East Germany would have to see itself as the executioner of this unfulfilled promise, the East German films indirectly admit that up to this point, party officials and organisations have not been able to win over the hearts of the younger ones. What bothers their Western peers has been elaborated above. Thus the films, across borders, form a network of intertextuality that mostly without directly quoting from each other provide a number of structural parallels which at least partially capture the milieu of that decade, but also foreground the difficulty of every generation as it passes into the world of adulthood with its irreconcilable contradictions. Because of the chronology in the release of one film and the planning and filming of a later one, Halbstarke and Berlin could have been able to quote The Wild One, but not Rebel without a Cause. The connection between Dieter and Johnny has already been mentioned, as has the habit of the policemen in both films to give second, third and more chances as well as their ability to interpret the silence of the youths. The nondiegetic warning to their audiences forms another link between Halbstarken and The Wild One.

But it is the nature of the problem itself that forces the use of similar character configurations and analogous plot patterns onto these films. The problem is there, there is always a cause, and a Bastille, but as they are too timid to advocate radical change the films within each social formation only have a limited repertoire of answers to the discontent. In the case of 1950s coming-of-age films, audiences were more than willing to be shown the path towards conformity. Nevertheless, while capitalising on the interest of audiences, the films also keep reminding viewers that there is always a cause to rebel against and a Bastille that should be stormed. And as long as there is one, new coming-of-age films will be made. Within the confines of 
the cinematic diegesis the vast problems seem manageable and thus the films offer a temporary escape from a more general cultural uneasiness. ${ }^{35}$

Friedemann J. Weidauer is a professor of German in the Department of Literatures, Cultures and Languages at the University of Connecticut.

\footnotetext{
-NOTES

1 The Wild One, dir. Laslo Benedek, Stanley Kramer Productions, 1953.

2 David M. Considine, The Cinema of Adolescence, McFarland, Jefferson and London, 1985, p. 188.

3 Jon Lewis, 'Growing Up Male in Jim's Mom's World', in J. David Slocum (ed.), Rebel without a Cause: Approaches to a Maverick Masterwork, SUNY Press, Albany NY, p. 94.

4 Timothy Shary, 'Teen Films: The Cinematic Image of Youth', in Barry Keith Grant (ed.), Film Genre

Reader III, University of Texas Press, Austin, 2003, p. 495.

5 Cf. ibid., p. 500.

${ }^{6}$ Considine, p. 239.

7 Cf. Thomas Sobchak, 'Genre: A Classical Experience', in Barry Keith Grant (ed.), Film Genre Reader III, University of Texas Press, Austin, 2003, pp. 109-10.

${ }^{8}$ Rebel Without a Cause, dir. Nicholas Ray, Warner Brothers, 1955; Die Halbstarken (usually translated as Teenage Wolfpack), West Germany, dir. Georg Tressler, Interwest, 1956); Berlin-Ecke Schönhauser (Berlin-Schonhauser Corner), East Germany, dir. Gerhard Klein, DEFA, 1957.

${ }^{9}$ Don DeLillo, Underworld, Scribner, New York, 1997.

10 Ibid., p. 803.

11 Ibid., p. 810.

12 Quoted in Considine, pp. 194-5.

13 Irgendwo in Berlin (Somewhere in Berlin), dir. Gerhard Lamprecht, DEFA, 1946.

14 Wim Wenders, Wim and Music<http://www.wim-wenders.com/music/wim_and_music.htm>.

15 US Bureau of Census as quoted in Fertility and Mortality in the United States

<http://eh.net/encyclopedia/article/haines.demography>, a trend reflected in the German context as well by Bundeszentrale für politische Bildung,

<http://www.bpb.de/wissen/00BM9A,0,0,Geburten.html>.

16 Current Population Reports <http://www.stanford.edu/class/polisci120a/immigration

/Median\%20Household\%20Income.pdf>.
} 
${ }^{17}$ For this section on the differences between the two generations see A. Dirk Moses' summary and evaluation of the debate in German Intellectuals and the Nazi Past, Cambridge University Press, 2009, pp. 56-72.

18 Ibid.

19 Ibid., p. 72.

${ }^{20}$ Cf. Jan Philipp Reemtsma, 'Generation ohne Abschied: Wolfgang Borchert als Angebot', in Jan Philipp Reemtsma, Der Vorgang des Erwachens nach dem Urknall: 10 Reden und Aufsätze, Haffmans Verlag, Zürich, 1995, pp. 28, 42.

${ }^{21}$ Cf. Thomas Doherty, Teenagers and Teenpics: The Juvenization of American Movies in the 1950s, Hymann, Boston, 1988, pp. ix-x.

22 Sobchak, pp. 110-12; Robin Wood, 'Ideology, Genre, Auteur', in Grant, p. 63-4.

${ }^{23}$ Cf. Karl Marx 347-77, 'Zur Judenfrage' in Marx und Engels Werke, Dietz Verlag, Berlin, 1978, pp. 34777.

24 Jon Lewis, The Road to Romance and Ruin: Teen Films and Youth Culture, Routledge, New York and London, 1992, p. 34.

25 Charles Ricks as quoted in Jon Lewis, The Road to Romance and Ruin: Teen Films and Youth Culture, Routledge, New York and London, 1992, p. 34.

26 Considine, p. 239.

27 Im Lauf der Zeit (Kings of the Road), dir. Wim Wenders, Filmverlag der Autoren, 1976.

28 The Searchers, dir. John Ford, Warner Brothers, 1956.

${ }^{29}$ Cf. George M. Wilson, 'Nicholas Ray's Rebel without a Cause', in Slocum, p. 111.

${ }^{30}$ Alexandra Seibel, 'The Imported Rebellion: Criminal Guys and Consumerist Girls in Postwar Germany and Austria', in Timothy Shary and Alexandra Seibel (eds), Youth Culture in Global Cinema, Texas University Press, Austin, 2007, pp. 29-30.

31 Cf. Slocum, 'Introduction: Rebel without a Cause, Fifty Years Later', in Slocum, pp. 4-5.

32 Seibel, p. 28.

33 Lewis, The Road to Romance and Ruin, p. 3.

${ }^{34}$ Herbert Marcuse, 'Repressive Toleranz', in Paul Wolff, Barrington Moore and Herbert Marcuse, Kritik der reinen Toleranz, Suhrkamp, Frankfurt, 1965.

${ }^{35}$ Cf. Wilson, p. 111.

\section{-BibliographY}

Considine, D.M., The Cinema of Adolescence, McFarland, Jefferson and London, 1985.

DeLillo, D., Underworld, Scribner, New York, 1997.

Dirk Moses, A., German Intellectuals and the Nazi Past, Cambridge University Press, 2009.

Doherty, T., Teenagers and Teenpics: The Juvenization of American Movies in the 1950s, Hymann, Boston, 1988. 
Grant, B.K. (ed.), Film Genre Reader III, University of Texas Press, Austin, 2003.

Lewis, J., 'Growing Up Male in Jim's Mom's World', in J.D. Slocum (ed.), Rebel without a Cause: Approaches to a Maverick Masterwork, SUNY Press, Albany NY, 2005.

Lewis, J., The Road to Romance and Ruin: Teen Films and Youth Culture, Routledge, New York and London, 1992.

Marcuse, H., 'Repressive Toleranz', in P. Wolff, B. Moore and H. Marcuse, Kritik der reinen Toleranz, Suhrkamp, Frankfurt, 1965.

Marx, K., 'Zur Judenfrage' in Marx und Engels Werke, Dietz Verlag, Berlin, 1978.

Reemtsma, J.P., 'Generation ohne Abschied: Wolfgang Borchert als Angebot', in J.P. Reemtsma, Der Vorgang des Eruabens nach dem Urknall: 10 Reden und Aufsätze, Haffmans Verlag, Zürich, 1995.

Seibel, A., 'The Imported Rebellion: Criminal Guys and Consumerist Girls in Postwar Germany and Austria', in T. Shary and A. Seibel (eds), Youth Culture in Global Cinema, Texas University Press, Austin, 2007.

Shary, T., 'Teen Films: The Cinematic Image of Youth', in B.K. Grant (ed.), Film Genre Reader III, University of Texas Press, Austin, 2003.

Slocum, J.D. (ed.), Rebel without a Cause: Approaches to a Maverick Masterwork, SUNY Press, Albany NY, 2005.

Slocum, J.D., 'Introduction: Rebel without a Cause, Fifty Years Later', in J.D. Slocum, Rebel without a Cause: Approaches to a Maverick Masterwork, SUNY Press, Albany NY, 2005.

Sobchak, T., 'Genre: A Classical Experience', in B.K. Grant (ed.), Film Genre Reader III, University of Texas Press, Austin, 2003.

Wenders, W., Wim and Music <http://www.wim-wenders.com/music/wim_and_music.htm>.

Wilson, G.M., 'Nicholas Ray's Rebel without a Cause', in J.D. Slocum, Rebel without a Cause: Approaches to a Maverick Masterwork, SUNY Press, Albany NY, 2005.

Wood, R. 'Ideology, Genre, Auteur', in B.K. Grant (ed.), Film Genre Reader III, University of Texas Press, Austin, 2003.

\section{-FILMS}

Benedek, L. (dir.), The Wild One, Stanley Kramer Productions, 1953.

Ford, J. (dir.), The Searchers, Warner Brothers, 1956.

Klein, G. (dir.), Berlin-Ecke Schönhauser, DEFA, 1957.

Lamprecht, G. (dir.), Irgendwo in Berlin, DEFA, 1946.

Ray, N. (dir.), Rebel Without a Cause, Warner Brothers, 1955.

Tressler, G. (dir.), Die Halbstarken, Interwest, 1956.

Wenders, Wim (dir.), Im Lauf der Zeit (Kings of the Road), Filmverlag der Autoren, 1976. 